\title{
1 Analysis of late Quaternary linear dune development in the Thar Desert, India.
}

2 Aayush Srivastava ${ }^{a}$, Julie A. Durcan ${ }^{\mathrm{a}}$ and David S.G. Thomas ${ }^{\mathrm{a}, \mathrm{b}}$

3 a School of Geography and the Environment, University of Oxford, Oxford, OX1 3QY, $4 \quad$ United Kingdom

b School of Geography, Archaeology and Environmental Studies, University of the

6 Witwatersrand, Johannesburg 2050, South Africa

${ }^{*}$ Corresponding author. E-mail address: aayush.srivastava@ouce.ox.ac.uk (A. Srivastava).

\section{Abstract}

Linear dunes are the most widespread dune type worldwide and act as important geoproxies of late Quaternary environmental change in deserts. They are less common in the Thar Desert, India than other dune types, especially parabolic forms, and to date their development history is poorly understood. Here we investigate a linear dunefield in the northern Thar through analysis of a series of excavated full dune profile sites and the application of optically stimulated luminescence (OSL) dating to provide chronometric control. Results show that linear dunes have been present since at least $\sim 58 \mathrm{ka}$ and were active throughout much of the Holocene. The early Holocene, a period marked by strong Indian summer monsoon winds (e.g., Gill et al., 2017), has been shown as the last major phase of dune accumulation recorded in all sites, with ages ranging from $~ 11.6-8.6 \mathrm{ka}$. Two spatially restricted records of dune accumulation have also been identified during the later part of Holocene: $\sim 4 \mathrm{ka}$ and $\sim 2-1 \mathrm{ka}$, attributed to localised reworking within the dunes. The suite of luminescence ages generated from the study region confirms the principle recognised in other dunefields (e.g., the southwest Kalahari; Stone and Thomas, 2008) and theoretically (Bailey and 
24 Thomas, 2014) that age records from individual dunes are unlikely to capture the developmental history of dunefields.

Keywords: Thar Desert, optically stimulated luminescence (OSL) dating, linear dunes, the Holocene, geomorphological change.

\section{Introduction}

A range of dune forms are present in the Thar Desert including parabolic, linear, transverse, star and network (e.g., Wasson et al., 1983; Kar, 1993; Moharana et al., 2013; Fig. 1A). The organisation and orientation of these dunes reflects the role of dominant south-west monsoon winds, which have governed aeolian dynamics regionally during the late Quaternary. The presence of superimposed forms, for example young meso-scale dunes on older, bigger parabolic dunes (Srivastava et al., 2019) attests to a more complex history of dune dynamics in the Thar.

Linear dunes, which are the most common desert dune type worldwide, including palaeo-dunes in semi-arid and arid landscapes (Lancaster, 1982; Tsoar, 1989) are relatively uncommon in the Thar. These dunes cover an area of approximately 11,200 $\mathrm{km}^{2}$, representing around $7.5 \%$ of all aeolian landforms in the Thar, where parabolic dunes are the most commonly observed dune type (Wasson et al., 1983; Kar, 1993; Moharana et al., 2013). Thar linear dunes occur mostly in the border zone between India and Pakistan in Jaisalmer district in the western part of the desert (Kar, 1987). Other studies have mapped smaller areas of linear dunes in the northern Thar near Bikaner (Saxena and Singh, 1976; Kumar et al., 1993) and the central Thar near Jodhpur (Verstappen, 1968; Kar, 1993) (Fig. 1A). Many of these smaller dunefields, 
47 however, have since been flattened to make way for the expansion of irrigated agriculture, removing landforms and prohibiting their analysis.

Linear dunes in the Thar have often been considered as an 'old system' (e.g., Pandey et al., 1964; Kar, 1993; Singhvi and Kar, 2004; Kar, 2014) with natural vegetation forming an integral part of the dune bodies. The length of these dunes varies across the Thar from more than $10 \mathrm{~km}$ in Jaisalmer to $1-2 \mathrm{~km}$ in Bikaner and includes dunes forms which vary from $\mathrm{Y}$-junctions to clusters of 5-8 linear dunes joining at acute angles which gradually merge with surrounding parabolic or transverse dunefields (Kar, 1987, 1993, 2014). The Y-junction pattern is similar to that of vegetated linear dunes in the north-western Negev (Tsoar and Moller, 1986; Tsoar et al., 2008) and south-western Kalahari (Thomas and Shaw, 1991; Bullard et al., 1995).

Linear dunes have the potential to offer long-term records of past aeolian episodes because of their accumulatory nature (Thomas 1992; Livingstone and Thomas, 1993; Munyikwa, 2005; Telfer et al., 2010), and thus are considered important geoproxy records (Telfer and Hesse, 2013; Thomas, 2013). The accumulation histories of linear dunes reconstructed using luminescence dating have been frequently and consistently used for palaeoenvironmental reconstructions in dryland environments, notably in southern Africa (e.g., Stokes et al., 1997, O'Connor and Thomas, 1999, Telfer and Thomas, 2007, Stone and Thomas, 2008), Australia (e.g., Lomax et al., 2003, Fitzsimmons et al., 2007), Israel (Roskin et al., 2011a,b) and the Arabian Peninsula (e.g., Glennie and Singhvi, 2002; Atkinson et al., 2013; Leighton et al., 2013). As a result, almost a third of the luminescence ages from drylands listed in the INQUA dune database are from linear dunes (Lancaster et al., 2016). In contrast, there are no ages in the database from linear dunes in the Thar Desert because the majority of chronometric studies to date have focussed on parabolic dunes (Thomas et al., 1999; 
72 Kar et al., 2001; Singhvi and Kar, 2004; Dhir et al., 2010; Srivastava et al., 2019). The

73 aim of this work therefore, is to apply a spatially intensive sampling strategy and

74 modern luminescence dating techniques to develop a linear dunefield chronology from

75 the Thar and integrate it into existing knowledge of the geomorphic evolution of the

76 Thar dunes and regional palaeoenvironmental interpretations arising from such 77 results. 


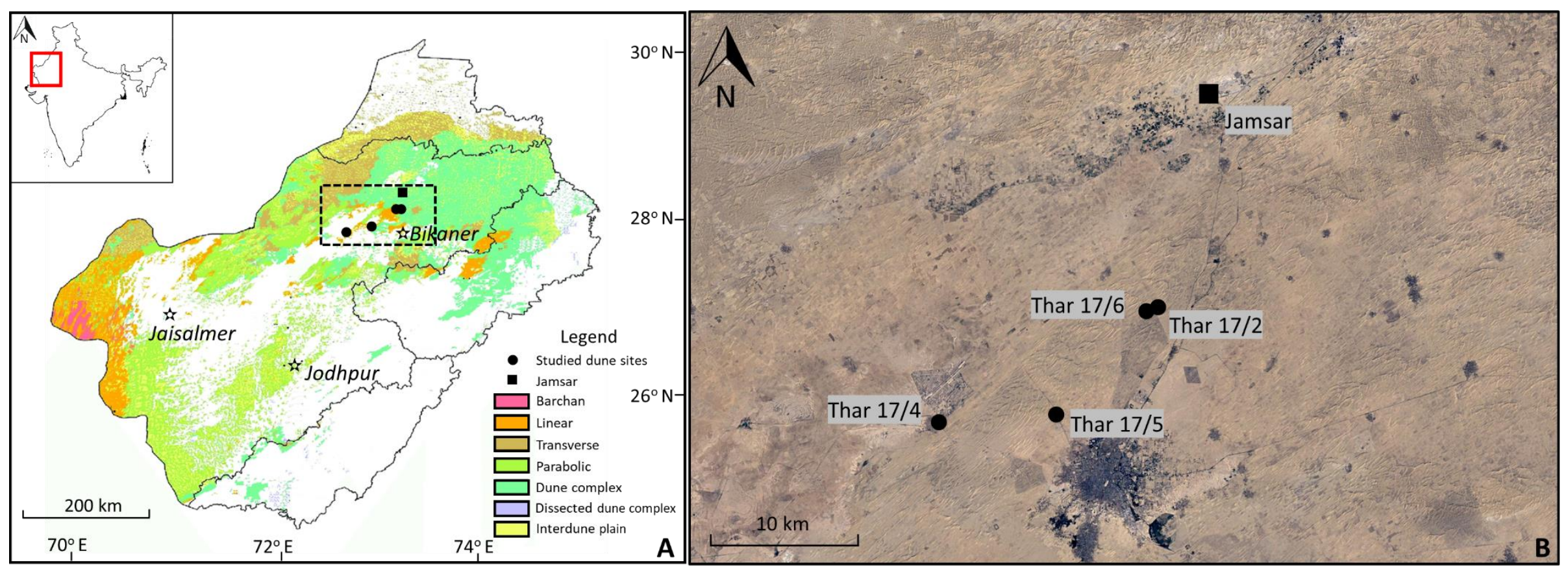

Fig. 1. A. Distribution of different dune types in the Thar Desert, India (after Moharana et al., 2013). B. Sampled linear dune sites (closed circles): Thar 17/2 (28.13728 N, 73.34283 E), Thar 17/4 (28.03315 N, 73.20950 E), Thar 17/5 (28.06017 N, 73.26852 E) and Thar $17 / 6(28.13641 \mathrm{~N}, 73.33286 \mathrm{E})$. 


\section{Study sites and methods}

84

85

\subsection{Study sites}

The focus of this study is a $\sim 500 \mathrm{~km}^{2}$ area of the linear dunefield in the Bikaner area of the northern Thar (Fig. 1B). This area was selected because of its central location, accessibility, and representativeness, based on Google Earth assessment of the linear dunes in the Thar. The Bikaner dunefield today comprises a semiarid to arid landscape with a mean annual precipitation of $200-300 \mathrm{~mm}$ and an interannual rainfall coefficient of variation of $47 \%$. The dunes here are colonised to a varying degree by natural vegetation such as Lasiurus sindicus, Capparis decidua, Calligonum polygonoides etc. Dunes range in height from $5 \mathrm{~m}$ to $20 \mathrm{~m}$ above the interdune areas and are $<10$ $\mathrm{km}$ in crestline length. The orientation of these dunes is in the SW direction controlled by the dominant Indian summer monsoon winds (Fig. 2A).

To identify the timing of periods of linear dune accumulation, field sampling for luminescence dating was conducted at four sites across the dunefield (Fig. 1B): Jaisalmer Bypass (Thar 17/2 and Thar 17/6), Nal (Thar 17/4) and Bajrang Dohra (Thar 17/5) sites. The two Jaisalmer Bypass sites, Thar $17 / 2$ and Thar 17/6, are located $<500 \mathrm{~m}$ apart near the northern edge of the dunefield. The other two sites, Thar $17 / 4$ and Thar $17 / 5$ fall in the central and south-central part of the dunefield. These were sampled to explore spatial and temporal variability in dune accumulation histories, with the number of sites analysed reflecting accessibility, the logistics of excavating exposures, and the number of samples generated that could effectively be dated while ensuring each sample location was represented by enough samples to capture accumulation histories. The sampled linear dunes are 9-12 $\mathrm{m}$ in height relative to the adjacent interdune area and aligned in the dominant direction of monsoon winds. At 
107 all four sites, the dune axis was targeted for sampling to obtain dune core sediment 108 presumed to have preserve the maximum thickness of sediments within the dune 109 bodies, and to be least affected by lateral dune movement. Sampled sections were 110 excavated on the crest of these dunes using hydraulic excavators until a hard, calcrete 111 rich layer, suggesting the base of the dune, was reached. The base of the dune was 112 reached at sites Thar $17 / 2,17 / 4$ and $17 / 5$, but not at Thar $17 / 6$, where risk of sediment 113 collapse prevented sampling. The dunes were composed of homogenous, usually 114 structureless sand with some fine laminations preserved in the top part of sampled 115 profiles. Sediment faces in the excavated pits were cleaned prior to sampling for 116 optically stimulated luminescence (OSL) dating. All samples were taken at least $0.5 \mathrm{~m}$ 117 below the modern dune surfaces and $0.5 \mathrm{~m}$ above a hard, calcrete layer, by 118 hammering black light-tight tubes into the cleaned sediment face. Sampling was 119 performed at a $1 \mathrm{~m}$ interval unless field examination revealed changes in stratigraphy 120 or sedimentology, in which case additional sampling was carried out to bracket such 121 features. 


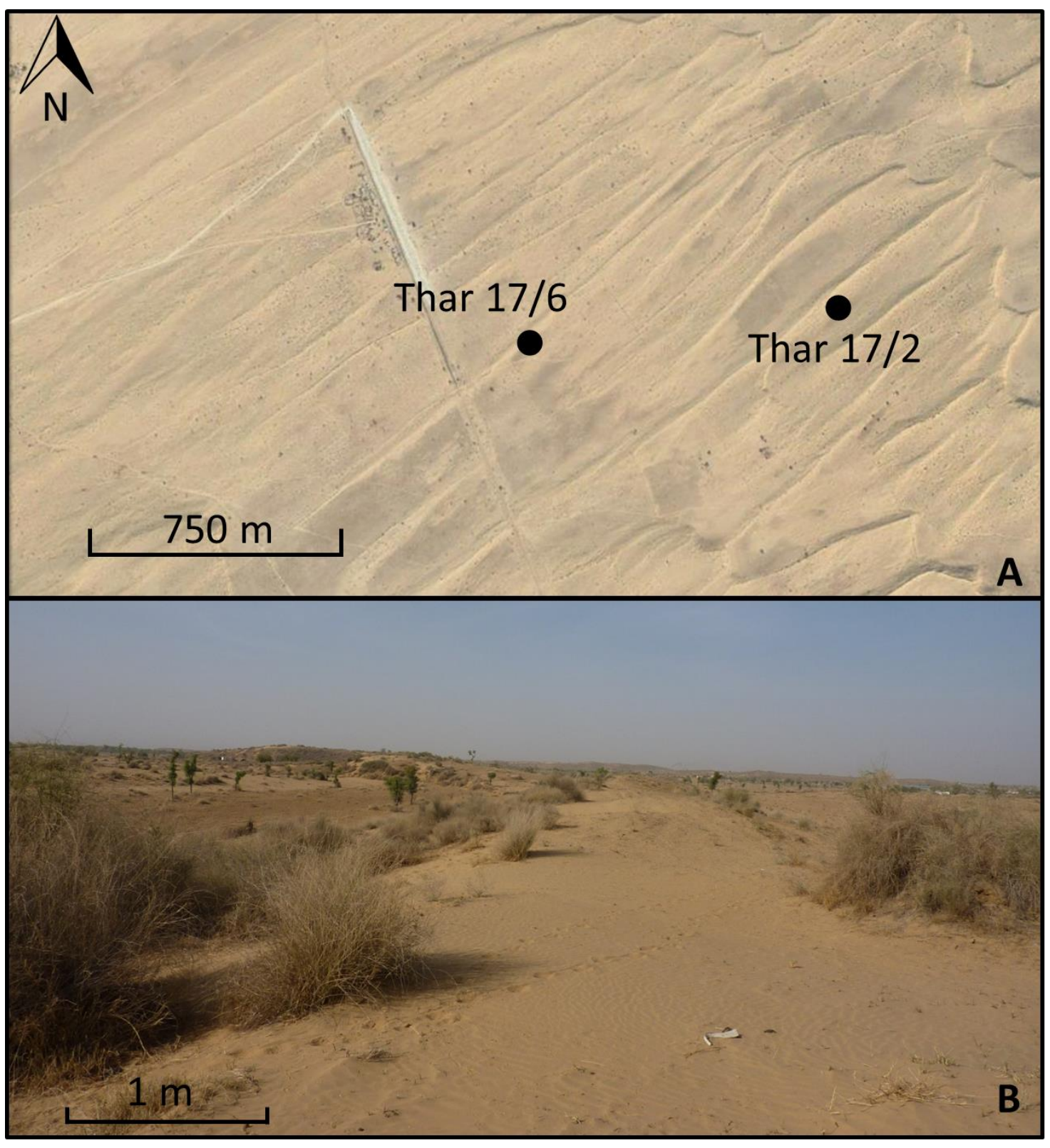

123 Fig. 2. A. Linear dune pattern in the Bikaner dunefield and location of two 124 studied sites. B. Landscape at site Thar 17/2. The photo is taken from the linear 125 dune crest facing in NE direction.

Grain size analyses were conducted using a Malvern Mastersizer Hydro 2000 laser analyser with wet dispersion. Statistics were calculated using Gradistat (Blott and Pye, 
2001) following the method of Folk and Ward (1957). Colour analysis was conducted on oven-dried samples using a Munsell colour chart. Organic and carbonate content were determined using sequential loss on ignition at $550^{\circ} \mathrm{C}$ and $950^{\circ} \mathrm{C}$ (Heiri et al., 2001) and expressed as a percentage of the sample weight.

\subsection{Sediment preparation for luminescence dating}

Samples were opened and prepared in subdued orange light conditions in the Oxford Luminescence Dating Laboratory. Prior to preparation of sediment for OSL dating, light-exposed sediments from the sample tube ends were removed and reserved for dose rate and sedimentological measurements. Sediments for luminescence dating were treated with hydrochloric acid and hydrogen peroxide to remove carbonate and organic matter, and sieved to isolate the $180-210 \mu \mathrm{m}$ grain size fraction. Quartz mineral grains were removed from the bulk sample using sodium polytungstate density separation, which was followed by chemical etching using hydrofluoric acid to remove the alpha-irradiated outer surface of the quartz grains and fluorosilicic acid to remove persistent feldspar contamination. After chemical etching, hydrochloric acid was used to remove any fluoride precipitate, prior to re-sieving. Fully prepared dry sediment was mounted onto aluminium discs as a $2 \mathrm{~mm}$ (small aliquot) monolayer consisting of $\sim 70$ grains (Heer et al., 2012) using Silkospray silicon oil.

\subsection{Equivalent dose determination}

Equivalent dose $\left(D_{e}\right)$ measurements were made using Risø DA-15 TL/OSL readers (for full reader specification see Srivastava et al., 2019) and a post-infrared blue single aliquot regenerative (SAR) dose protocol (Banerjee et al., 2001). Following pre-heat 
plateau and dose recovery tests, a pre-heat of $240^{\circ} \mathrm{C}$ for $10 \mathrm{~s}$ and a cut-heat of $160^{\circ} \mathrm{C}$ for $0 \mathrm{~s}$ were selected for use. The protocol comprised an infrared light $(870 \mathrm{~nm})$ stimulation at $50^{\circ} \mathrm{C}$ for $100 \mathrm{~s}$ prior to measurement of the blue-light stimulated ultraviolet luminescence signals at $125^{\circ} \mathrm{C}$ for $40 \mathrm{~s}$. Dose recovery tests on samples Thar $17 / 2 / 4,17 / 4 / 8,17 / 5 / 1,17 / 6 / 2$, and 17/6/6, provided ratios of $0.94 \pm 0.04,0.95 \pm 0.04$, $1.00 \pm 0.06,1.00 \pm 0.07$, and $0.96 \pm 0.05$, respectively, indicating the suitability of the applied protocol. To ascertain the average number of luminescing signals, single grain analyses of samples on samples Thar $17 / 2 / 4$, Thar $17 / 4 / 2$, Thar $17 / 4 / 8$, Thar $17 / 5 / 6$, Thar 17/6/6 and Thar 17/6/9 was undertaken, and showed that between 2.4 and 5.0 $\%$ of the measured 500 grains gave a discernible luminescence signal after a 50 Gy dose.

Luminescence signals were included in final $D_{e}$ calculation when the following rejection criteria were satisfied: 1 ) recuperation less than $5 \%$ (where sample $D_{e}$ was greater than $1.5 \mathrm{~Gy}$ ) or $0.25 \mathrm{~Gy}$ (for $\mathrm{Des}_{\mathrm{e}}$ less than $1.5 \mathrm{~Gy}$ ); 2) recycling ratio within 10 $\%$ of unity, including uncertainties (Murray and Wintle, 2003); and 3) test dose signals $3 \sigma$ greater than the background. Final $D_{e}$ determinations for each sample were based upon at least 20 accepted aliquots and were calculated in the $\mathrm{R}$ Luminescence package (Kreutzer et al., 2017) using the central age model (CAM) (Galbraith et al., 1999).

\subsection{Dose rate determination}

175 Radionuclide concentrations ( ${ }^{232} \mathrm{Th},{ }^{238} \mathrm{U}$ and ${ }^{40} \mathrm{~K}$ ) were measured using inductively coupled plasma mass spectrometry at the Scottish University Environmental Research Centre, East Kilbride. Infinite-matrix dose rates were calculated using the 


\section{8}

conversion factors of Guerin et al. (2011) and were adjusted for attenuation by grain size and chemical etching using the datasets of Guerin et al. (2012) and Bell (1979) respectively, as well as a moisture content of $5 \pm 2 \%$. Following Prescott and Hutton (1994), cosmic dose rates were determined from sample longitude, latitude, altitude, and depth. All dose rate calculations were made using the DRAC (v1.2) software of Durcan et al. (2015).

\section{Results}

\subsection{Sedimentology}

Sedimentological data are provided in Table 1. The samples are consistent in colour within each dune. The majority of samples are unimodal (Fig. 3A), predominantly composed of medium to fine sand, with silt and clay components varying between 0 $23.5 \%$ and $0-1.2 \%$ respectively (Fig. 3B). Mean grain sizes are within the range of 105-220 $\mu \mathrm{m}$, comparable with linear dune sediments, for example in north-eastern Rub' al Khali in Arabia (Leighton et al., 2013) and the north-western Negev (Roskin et al., 2011a). Most samples are well to moderately well sorted with symmetrical and mesokurtic distributions (Table 1). The organic content by weight is less than $2 \%$, while carbonate content by weight increases with depth in a section, varying between $\sim 1$ and $\sim 5 \%$. These organic and carbonate values are consistent with other recently reported values from Thar parabolic dune sands (Srivastava et al., 2019). 


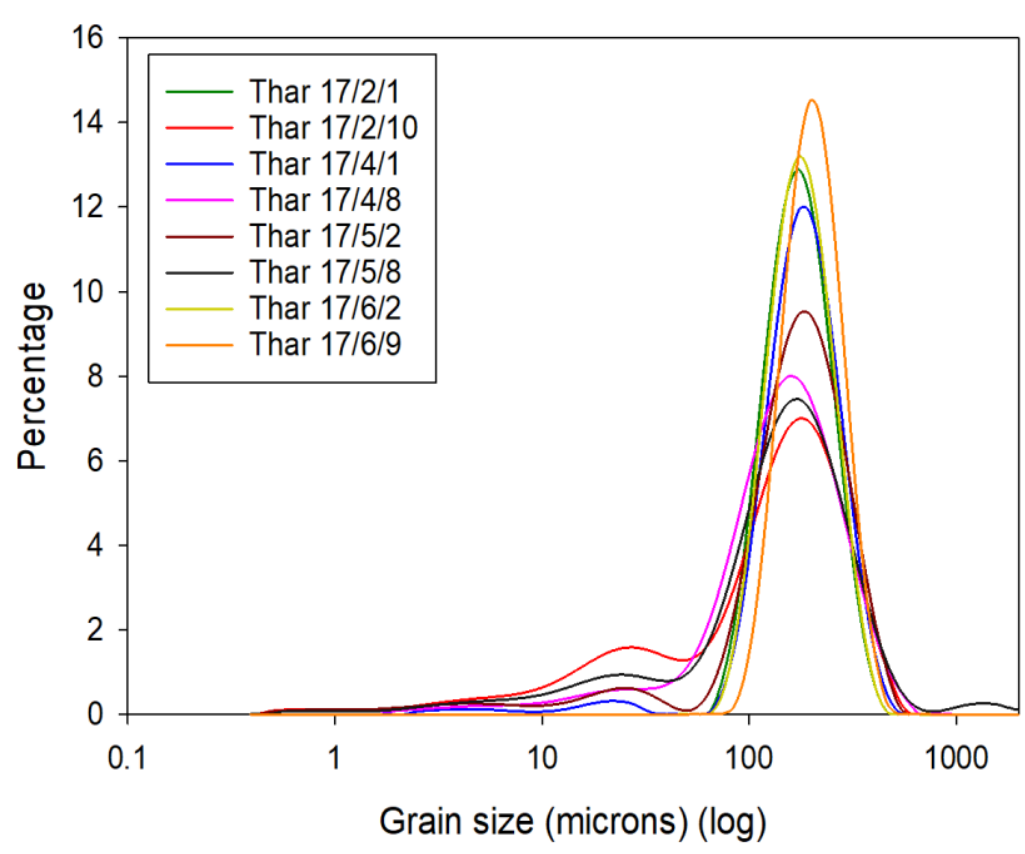

A

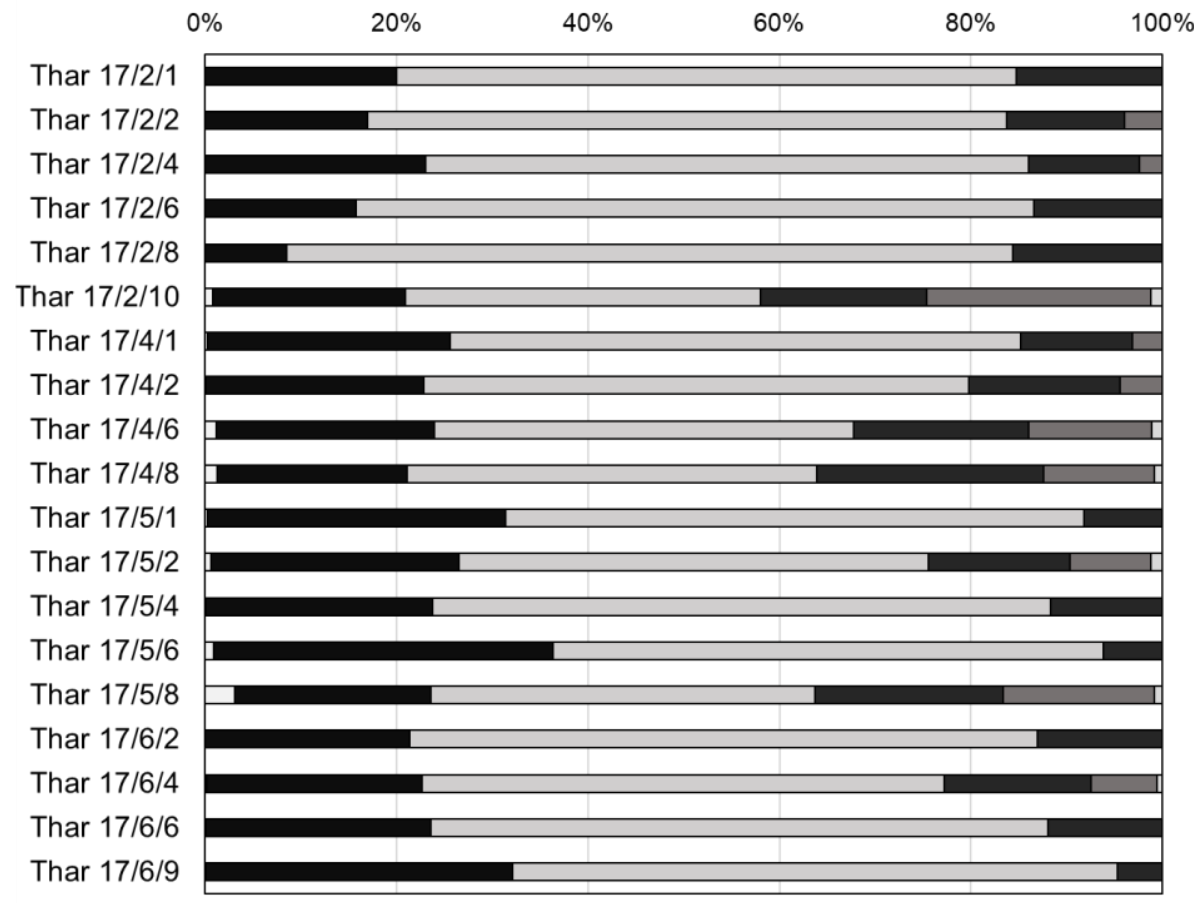

B

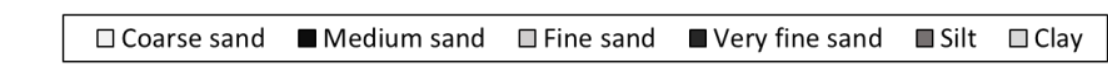

Fig. 3. A. Grain size distribution by volume for selected samples from each sampled dune. B. The percentage distribution of different grain sizes for all the samples. Clay $<2 \mu \mathrm{m}$; silt $=2-63 \mu \mathrm{m}$; very fine sand $=63-125 \mu \mathrm{m}$; fine sand $=125-250 \mu \mathrm{m}$, medium sand $=250-500$ $\mu \mathrm{m}$; and coarse sand $=$ 500-1000 $\mu \mathrm{m}$ (Blott and Pye, 2001 and references therein). 
Table 1. Sedimentology of samples showing Munsell colour, grain size statistics (in microns), organic and carbonate content.

\begin{tabular}{|c|c|c|c|c|c|c|c|c|c|c|c|c|c|}
\hline Sample & Munsell & 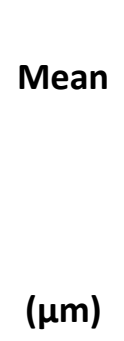 & $\begin{array}{l}\text { Coarse } \\
\text { sand } \\
(500- \\
1000 \\
\mu \mathrm{m}) \\
(\%)\end{array}$ & $\begin{array}{l}\text { Medium } \\
\text { sand } \\
(250- \\
500 \mu \mathrm{m}) \\
(\%)\end{array}$ & $\begin{array}{l}\text { Fine } \\
\text { sand } \\
(125- \\
250 \\
\mu \mathrm{m}) \\
(\%)\end{array}$ & $\begin{array}{l}\text { Very } \\
\text { fine } \\
\text { sand } \\
(63- \\
125 \\
\mu \mathrm{m}) \\
(\%)\end{array}$ & $\begin{array}{c}(2-63 \\
\mu \mathrm{m})(\%)\end{array}$ & $\begin{array}{l}(<2 \\
\mu \mathrm{m}) \\
(\%)\end{array}$ & Sorting* & Skewness** & Kurtosis*** & $\begin{array}{c}\text { content } \\
\text { (\%) }\end{array}$ & $\begin{array}{c}\text { content } \\
(\%)\end{array}$ \\
\hline Thar 17/2/1 & 10 YR 5/4 & 183.0 & 0.0 & 20.0 & 64.7 & 15.3 & 0.0 & 0.0 & 1.439 (MWS) & $-0.001(S)$ & $0.952(\mathrm{M})$ & 0.62 & 1.80 \\
\hline Thar $17 / 2 / 2$ & 10 YR 5/4 & 178.5 & 0.0 & 17.0 & 66.7 & 12.3 & 4.0 & 0.0 & 1.447 (MWS) & $-0.086(S)$ & $1.072(\mathrm{M})$ & 0.76 & 2.31 \\
\hline Thar $17 / 2 / 4$ & 10 YR 5/4 & 188.8 & 0.0 & 23.0 & 63.0 & 11.6 & 2.4 & 0.0 & 1.459 (MWS) & $-0.037(S)$ & 0.994 (M) & 0.87 & 2.80 \\
\hline Thar $17 / 2 / 6$ & 10 YR 5/4 & 179.9 & 0.0 & 15.8 & 70.8 & 13.4 & 0.0 & 0.0 & 1.382 (WS) & $0.000(\mathrm{~S})$ & $0.956(\mathrm{M})$ & 0.72 & 2.10 \\
\hline Thar $17 / 2 / 8$ & 10 YR 5/4 & 168.3 & 0.0 & 8.5 & 75.9 & 15.6 & 0.0 & 0.0 & 1.336 (WS) & $0.001(S)$ & 0.965 (M) & 0.60 & 3.88 \\
\hline Thar 17/2/10 & 10YR 5/4 & 106.8 & 0.8 & 20.1 & 37.1 & 17.4 & 23.4 & 1.2 & 3.114 (PS) & -0.470 (VFS) & $1.226(\mathrm{~L})$ & 1.36 & 3.94 \\
\hline Thar $17 / 4 / 1$ & 10 YR 6/4 & 191.1 & 0.3 & 25.3 & 59.6 & 11.7 & 3.1 & 0.0 & 1.500 (MWS) & $-0.051(\mathrm{~S})$ & $1.013(\mathrm{M})$ & 0.58 & 1.70 \\
\hline Thar $17 / 4 / 2$ & 10 YR 6/4 & 180.2 & 0.1 & 22.8 & 56.9 & 15.8 & 4.4 & 0.0 & 1.569 (MWS) & $-0.088(S)$ & $1.063(\mathrm{M})$ & 0.87 & 2.24 \\
\hline Thar $17 / 4 / 6$ & 10 YR $6 / 4$ & 154.3 & 1.2 & 22.8 & 43.8 & 18.2 & 12.9 & 1.1 & 2.399 (PS) & -0.356 (VFS) & 1.747 (VL) & 0.71 & 2.60 \\
\hline Thar $17 / 4 / 8$ & 10 YR 6/4 & 149.0 & 1.3 & 19.8 & 42.8 & 23.7 & 11.6 & 0.8 & 2.192 (PS) & $-0.258(\mathrm{FS})$ & $1.463(\mathrm{~L})$ & 0.98 & 5.06 \\
\hline Thar $17 / 5 / 1$ & 10 YR $6 / 4$ & 208.3 & 0.3 & 31.1 & 60.4 & 8.2 & 0.0 & 0.0 & 1.441 (MWS) & $-0.006(S)$ & $0.952(\mathrm{M})$ & 0.88 & 1.90 \\
\hline Thar $17 / 5 / 2$ & 10 YR 6/4 & 176.6 & 0.6 & 25.9 & 49.1 & 14.8 & 8.5 & 1.2 & 2.134 (PS) & -0.322 (VFS) & $1.877(\mathrm{VL})$ & 0.87 & 1.96 \\
\hline Thar $17 / 5 / 4$ & 10 YR $6 / 4$ & 192.4 & 0.1 & 23.7 & 64.5 & 11.7 & 0.0 & 0.0 & 1.429 (MWS) & $0.006(S)$ & $0.952(\mathrm{M})$ & 0.51 & 2.10 \\
\hline Thar $17 / 5 / 6$ & 10 YR $6 / 4$ & 219.0 & 0.9 & 35.5 & 57.4 & 6.2 & 0.0 & 0.0 & 1.446 (MWS) & $0.009(\mathrm{~S})$ & $0.952(\mathrm{M})$ & 0.48 & 2.48 \\
\hline Thar $17 / 5 / 8$ & 10 YR $6 / 4$ & 140.4 & 3.1 & 20.5 & 40.1 & 19.9 & 15.8 & 0.8 & 2.584 (PS) & -0.343 (VFS) & $1.567(\mathrm{VL})$ & 1.65 & 3.85 \\
\hline Thar $17 / 6 / 2$ & 10 YR $5 / 4$ & 187.5 & 0.0 & 21.4 & 65.5 & 13.1 & 0.0 & 0.0 & 1.425 (MWS) & $0.002(S)$ & 0.946 (M) & 0.60 & 1.09 \\
\hline Thar $17 / 6 / 4$ & 10 YR 5/4 & 175.7 & 0.2 & 22.5 & 54.5 & 15.3 & 6.9 & 0.6 & 1.932 (MS) & -0.295 (FS) & $1.838(\mathrm{VL})$ & 0.59 & 2.20 \\
\hline Thar $17 / 6 / 6$ & 10 YR $5 / 4$ & 191.7 & 0.1 & 23.5 & 64.4 & 12.0 & 0.0 & 0.0 & 1.431 (MWS) & $0.007(S)$ & $0.951(\mathrm{M})$ & 0.56 & 3.21 \\
\hline Thar $17 / 6 / 9$ & 10 YR 5/4 & 214.6 & 0.1 & 32.0 & 63.2 & 4.7 & 0.0 & 0.0 & 1.381 (WS) & $-0.003(S)$ & $0.956(\mathrm{M})$ & 0.52 & 2.78 \\
\hline
\end{tabular}


** $\mathrm{FS}=$ finely skewed, $\mathrm{VFS}=$ very finely skewed, $\mathrm{S}=$ symmetrical.

*** $\mathrm{L}=$ leptokurtic, $\mathrm{VL}=$ very leptokurtic, $\mathrm{M}=$ mesokurtic 
In general, measured luminescence signals from small aliquots are bright enough to be discernible from the background (Fig. 4A) and are dominated by the quartz fast component in the initial part of the OSL signal (fast ratio > 20; Durcan and Duller, 2011). Single grain analyses confirm the low levels of luminescence sensitivity to dose (2-3 luminescing grains per disc), which ensures that any heterogeneity in $D_{e}$ distributions should be identified. The heterogeneity or over-dispersion $\left(\sigma_{d}\right)$, in $D_{e}$ distributions for the majority samples in this study ranges between $20 \%$ and $45 \%$ (Table 2), with slightly higher values ( 45\%) observed for two of the younger samples. These $\sigma_{d}$ values are in line with values calculated from other single aliquots of dune samples in the central Thar $\left(\sigma_{d}=20-40 \%\right.$; Srivastava et al., 2019), single grains of dune samples from the northern Thar margin ( $\sigma_{d}=30-50 \%$; Durcan et al., 2019) and are comparable to linear dunes studies elsewhere (e.g., the Negev, $\sigma_{d}=10-60 \%$; Roskin et al., 2011a). Overdispersion can be caused by a combination of intrinsic factors, such as natural variability of quartz (Thomsen et al., 2012 and references therein), as well as extrinsic sources, such as heterogenous bleaching (e.g., Olley et al., 2004), post-depositional mixing of sediments (e.g., Bateman et al., 2003; 2007; Kristensen, 2015), and dosimetric variability (e.g., Nathan et al., 2003; Mayya et al., 2006); and instrumental sources which have a small contribution (e.g., Thomsen et al., 2005; Cunningham et al., 2011). As discussed, the observed $\sigma_{d}$ values for this suite of data is relatively low, and in line with other published values from aeolian, dryland contexts. $\sigma_{d}$ values from dose recovery tests were $<5 \%$, and therefore we hypothesise external factors as the source of the observed variability. $\sigma_{d}$ due to incomplete bleaching is unlikely, given the deposition by aeolian processes (Duller, 2004; Singhvi and Porat, 2008), and samples were carefully collected from visibly 
237 undisturbed strata, which should minimise $D_{e}$ variability as a result of post-depositional 238 mixing. We, therefore, hypothesise mild microdosimetric variability as a source of 239 variability in $D_{e}$ distributions. It has been demonstrated empirically and through 240 modelling that microdosimetric variability may contribute significantly to variations in 241 Des for well-bleached samples (up to 45- 50 \%; see Mayya et al., 2006; Cunningham et al., 2012; Guérin et al., 2015; Jankowski and Jacobs, 2018). In this context of relatively low $\sigma_{d}$ values, which are in line with other published studies, and given that the $D_{e}$ distributions tend to be symmetrical around a central value (e.g., Fig. 4B), the al. (2019).
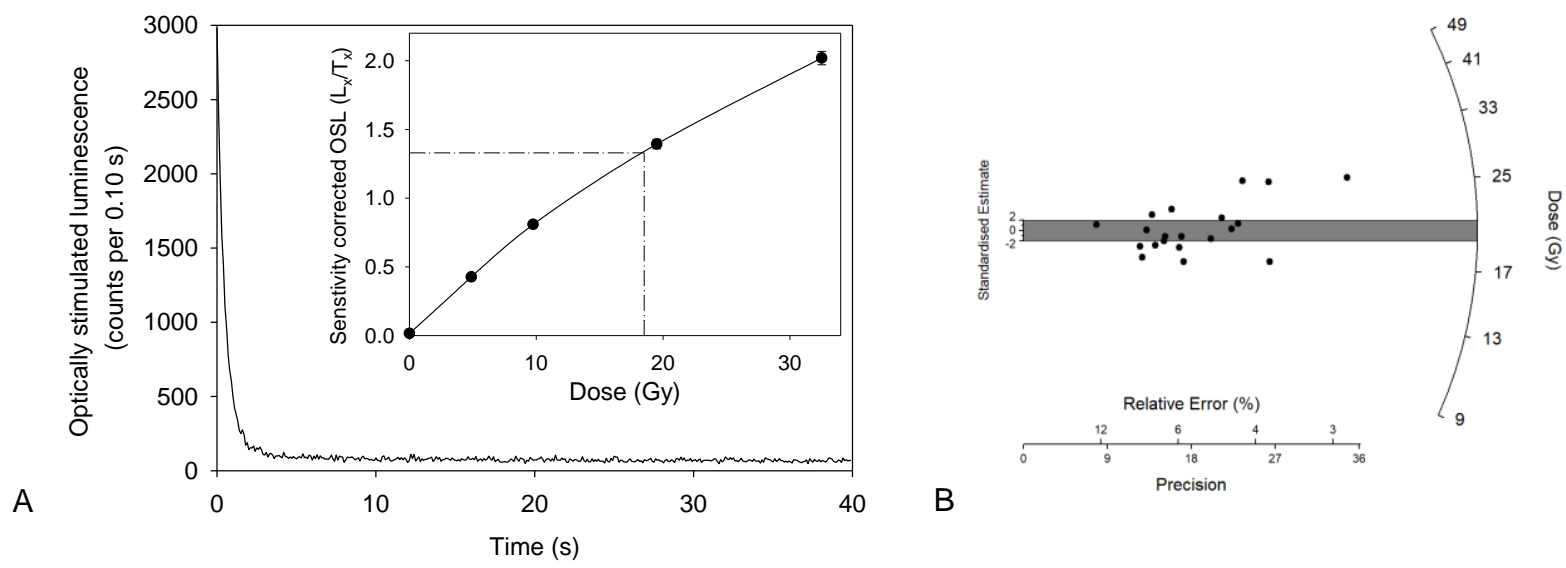

248

Fig. 4. A. An example OSL signal from sample Thar $17 / 2 / 6$, and the dose response curve from the same aliquot (inset) B. Radial plot of individual $D_{e}$ s for Thar $17 / 2 / 6\left(\sigma_{d}=23 \%\right)$. 
257 One of the factors which limits the upper dateable range of OSL dating is signal 258 saturation. A quartz OSL signal can be considered saturated if either the natural signal does not intercept the dose response curve (DRC) or if the natural signal interpolates onto the flat, asymptotic part of the DRC (e.g., Fig. 5). Interpolation of the natural signal from the asymptote of the saturated DRC results in a large and asymmetric uncertainty in $D_{e}$ (Murray et al., 2002; Murray and Funder, 2003) and therefore should be avoided where possible. Wintle and Murray (2006) suggest that a prudent upper dating limit for saturated signals is the $2 \mathrm{D}$ o parameter, which represents $\sim 85 \%$ of the upper saturation point obtained from the DRC. $D_{0}$ is derived from the fitting of the $\mathrm{DRC}$ with a single saturating exponential function, $\mathrm{I}=\mathrm{I}_{0}\left(1-\exp ^{\mathrm{D} / \mathrm{D} 0}\right)$ where $\mathrm{I}$ is the $\mathrm{OSL}$ intensity after a dose (D), $I_{0}$ is the saturation intensity and $D_{0}$ is the dose level characteristic of the DRC (Wintle and Murray, 2006).

In this study, a signal was considered saturated if there was no interpolation on the DRC or if the calculated $D_{e}$ was greater than $2 D_{0}$. A sample was considered saturated when more than $50 \%$ of measured accepted aliquots were saturated, and a minimum age was calculated using the mean $2 \mathrm{D}_{0}$ values of all accepted aliquots. These minimum ages are reported to the nearest integer and without an uncertainty, reflecting that the 'true' $D_{e}$ is in excess of quoted minimum. Two samples are considered saturated (Table 2): Thar 17/2/10 (15/27 aliquots saturated) and Thar $17 / 5 / 8(14 / 24)$ and yielded minimum ages of $>58 \mathrm{ka}$ and $>48$ ka respectively. 


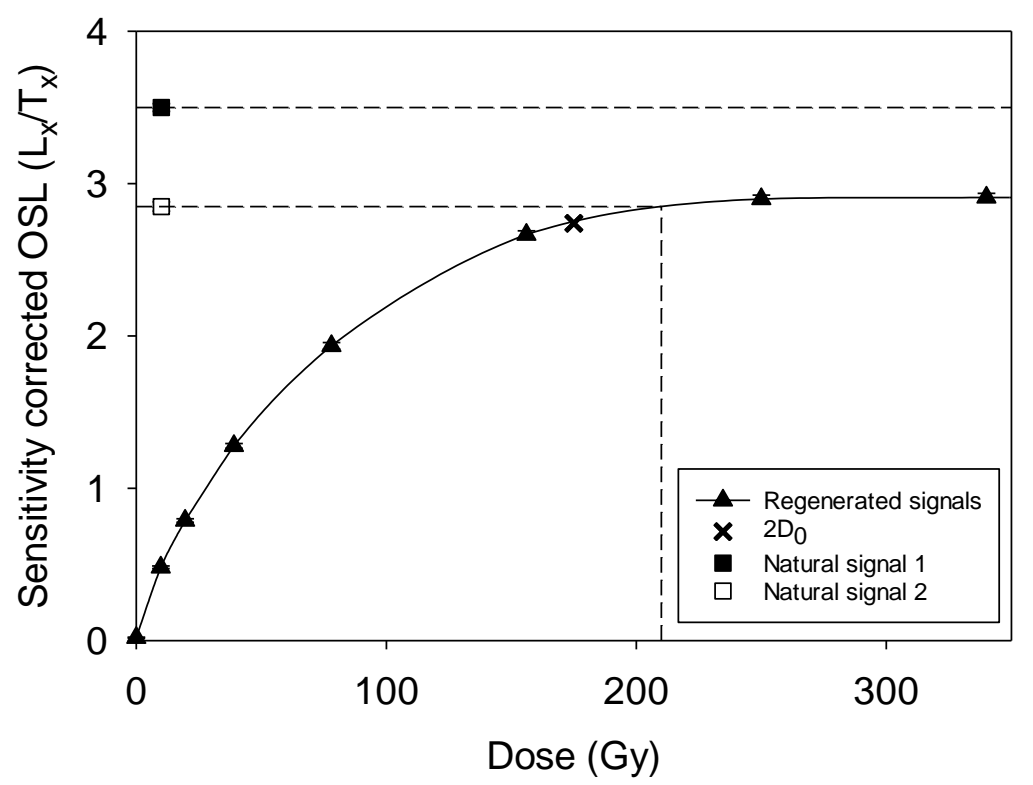

Fig. 5. The two types of OSL signal considered saturated in this study. i) where natural signal does not intercept the dose response curve (natural signal 1 square symbol) and ii) when the interpolated $D_{e}$ exceeds 2Do (natural signal 2 open square symbol).

\subsubsection{Luminescence ages}

A summary of the luminescence dating results is provided in Table 2 along with stratigraphic sections (Fig. 6A) and age-depth profiles (Fig. 6B). At all four sites, OSL ages (including uncertainties) are in stratigraphic order and 17 of the 19 samples date to the Holocene, 10 of which date to the early part of the Holocene. Site Thar $17 / 2$ depicts a Pleistocene feature with the oldest age at $9 \mathrm{~m}$ depth having a minimum age of $>58 \mathrm{ka}$. At 7 and $3 \mathrm{~m}$ depths, sample ages are within uncertainties: $8.81 \pm 0.71 \mathrm{ka}$ (Thar 17/2/8) and $8.62 \pm 0.64$ ka (Thar 17/2/4) old respectively. Sample Thar 17/2/1 shows that the uppermost $0.8 \mathrm{~m}$ of dune sediments accumulated in the last $\sim 500$ years (Thar 17/2/1) and is immediately underlain by a $4.07 \pm 0.44$ ka old sample at $0.9 \mathrm{~m}$ 
293 (Thar 17/2/2). The five samples from Thar $17 / 5$ dune show a similar dune 294 accumulation pattern to Thar 17/2 where the basal dune unit is atleast $\sim 48$ ka old (Thar $29517 / 5 / 8$ ) and is overlain by $2 \mathrm{~m}$ dune which accumulated between $9.38 \pm 0.82 \mathrm{ka}$ (Thar $29617 / 5 / 6)$ and $9.27 \pm 0.64 \mathrm{ka}$ (Thar 17/5/4). The top $1.6 \mathrm{~m}$ of sediments at Thar $17 / 5$ 297 recorded dune activity in the last $\sim 150$ years (Thar $17 / 5 / 1$ ). The site $17 / 4$ preserves 298 only Holocene accumulation with the oldest sample at $11 \mathrm{~m}$ dating to $11.61 \pm 0.82 \mathrm{ka}$ 299 (Thar 17/4/8). $7 \mathrm{~m}$ of dune sand accumulation occurred between $10.52 \pm 0.99 \mathrm{ka}$ (Thar $30017 / 4 / 6)$ and $8.79 \pm 0.67 \mathrm{ka}$ (Thar 17/4/2). The uppermost sample, taken $0.5 \mathrm{~m}$ below 301 the dune surface, dates to $3.01 \pm 0.24 \mathrm{ka}$ (Thar 17/4/1). At site Thar 17/6, between 9.5 302 and $6 \mathrm{~m}$ down section, sample ages are within uncertainties- $9.39 \pm 0.69$ ka (Thar $30317 / 6 / 9)$ and $9.38 \pm 0.71 \mathrm{ka}$ (Thar 17/6/6) old. The top $2 \mathrm{~m}$ dune is recent, dating from 304 $0.34 \pm 0.03$ ka (Thar 17/6/2).

305 306 

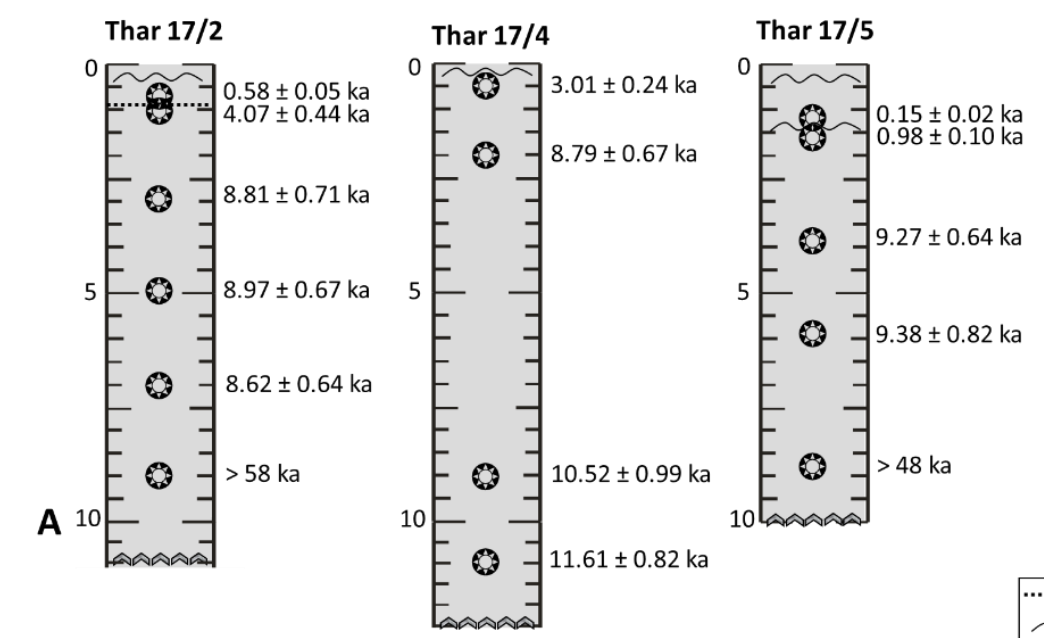

Thar 17/6
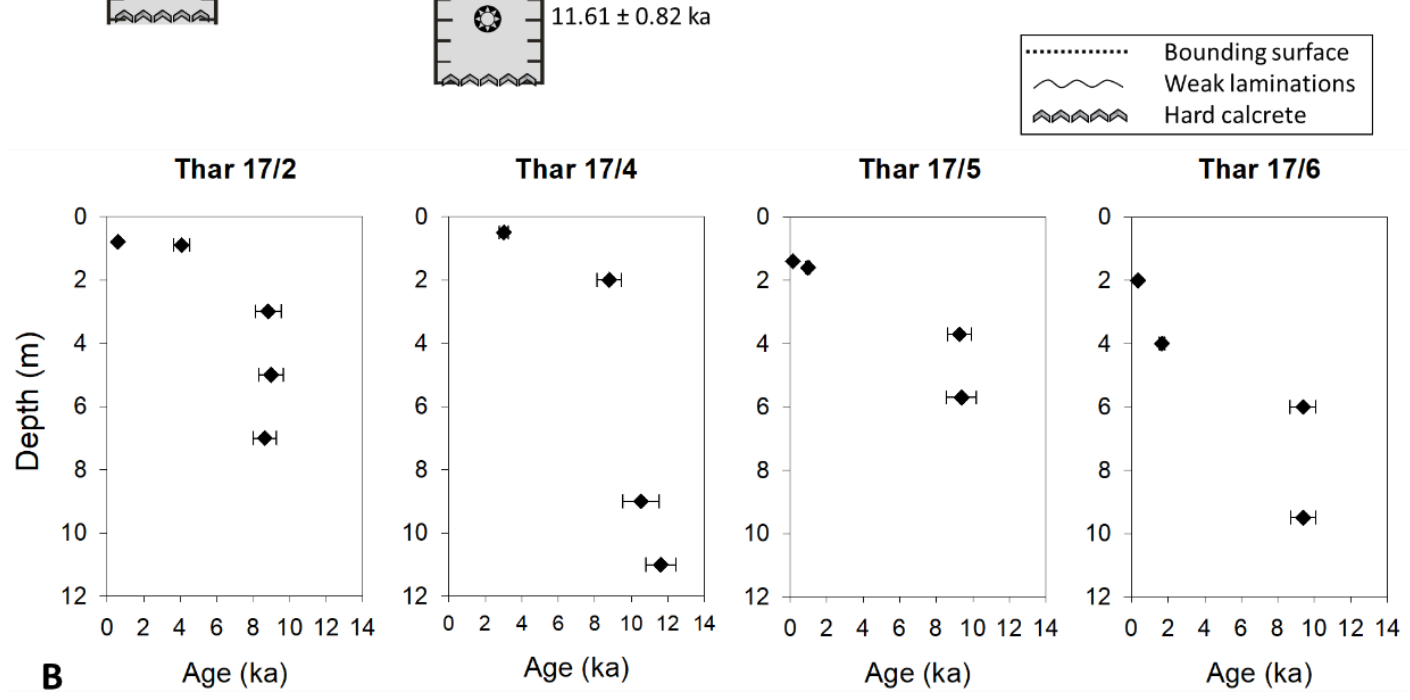

Fig. 6. A. Stratigraphic sections and OSL ages for the sampled sites investigated in this study. Sample depth are in metres. Note the sections comprised largely homogenous and structureless sand with very few laminations or other sedimentological features. B. Agedepth profiles for all four sites. The minimum ages for samples Thar 17/2/10 (>58 ka) and 17/5/8 (>48 ka) are not displayed. 
Table 2. Summary OSL data. Equivalent doses $\left(D_{e}\right)$, dose rates $(\dot{D})$, and ages are shown to two decimal places, with all calculations made prior to rounding.

Minimum $D_{e} s$ and ages are calculated for samples Thar $17 / 2 / 10$ and Thar $17 / 5 / 8$ due to signal saturation and are quoted to the nearest int eger, without

uncertainties. All ages are relative to the year 2018.

\begin{tabular}{|c|c|c|c|c|c|c|c|c|c|}
\hline Sample & $\begin{array}{l}\text { Depth } \\
\text { (m) }\end{array}$ & $\begin{array}{c}\text { Discs accepted } \\
\text { (measured) }\end{array}$ & $\begin{array}{c}\text { Over-dispersion } \\
\text { (\%) }\end{array}$ & $\begin{array}{l}D_{e} \\
(G y)\end{array}$ & $\begin{array}{c}\text { Beta D } \\
(\text { Gy.ka-1 })\end{array}$ & $\begin{array}{l}\text { Gamma D } \\
\left(\text { Gy.ka }{ }^{-1}\right)\end{array}$ & $\begin{array}{l}\text { Cosmic D } \\
\left(G y \cdot k^{-1}\right)\end{array}$ & $\begin{array}{l}\text { Envir D } \\
\left(\text { Gy.ka }{ }^{-1}\right)\end{array}$ & $\begin{array}{l}\text { Age } \\
\text { (ka) }\end{array}$ \\
\hline $\operatorname{ar} 17 / 2 / 1$ & 0.8 & $26(38)$ & $34.3 \pm 4.8$ & $1.22 \pm 0.08$ & $1.24 \pm 0.11$ & $0.68 \pm 0.05$ & $0.19 \pm 0.02$ & $2.10 \pm 0.12$ & $0.58 \pm 0.05$ \\
\hline har $17 / 2 / 2$ & 0.9 & $22(36)$ & $36.6 \pm 6.1$ & $8.36 \pm 0.78$ & $1.17 \pm 0.10$ & $0.71 \pm 0.05$ & $0.18 \pm 0.02$ & $2.06 \pm 0.11$ & $4.07 \pm 0.44$ \\
\hline $\operatorname{ar} 17 / 2 / 4$ & 3.0 & $25(46)$ & $28.0 \pm 4.0$ & $19.74 \pm 1.18$ & $1.25 \pm 0.11$ & $0.85 \pm 0.05$ & $0.14 \pm 0.01$ & $2.24 \pm 0.12$ & $8.81 \pm 0.71$ \\
\hline har $17 / 2 / 6$ & 5.0 & $21(43)$ & $22.3 \pm 3.7$ & $19.82 \pm 1.04$ & $1.24 \pm 0.10$ & $0.86 \pm 0.06$ & $0.11 \pm 0.01$ & $2.21 \pm 0.12$ & $8.97 \pm 0.67$ \\
\hline har $17 / 2 / 8$ & 7.0 & $21(27)$ & $24.3 \pm 3.8$ & $19.64 \pm 1.05$ & $1.25 \pm 0.10$ & $0.94 \pm 0.06$ & $0.09 \pm 0.01$ & $2.28 \pm 0.12$ & $8.62 \pm 0.64$ \\
\hline $\operatorname{nar} 17 / 2 / 10$ & 9.0 & $27(30)$ & - & $>125$ & $1.26 \pm 0.11$ & $0.82 \pm 0.05$ & $0.08 \pm 0.01$ & $2.15 \pm 0.12$ & $>58$ \\
\hline har $17 / 4 / 1$ & 0.5 & $21(32)$ & $28.4 \pm 4.4$ & $8.24 \pm 0.51$ & $1.44 \pm 0.11$ & $1.10 \pm 0.07$ & $0.21 \pm 0.02$ & $2.74 \pm 0.14$ & $3.01 \pm 0.24$ \\
\hline har $17 / 4 / 2$ & 2.0 & $24(35)$ & $27.0 \pm 3.9$ & $20.39 \pm 1.13$ & $1.27 \pm 0.10$ & $0.89 \pm 0.06$ & $0.16 \pm 0.02$ & $2.32 \pm 0.12$ & $8.79 \pm 0.67$ \\
\hline har $17 / 4 / 6$ & 9.0 & $24(48)$ & $37.0 \pm 5.5$ & $24.97 \pm 1.94$ & $1.35 \pm 0.11$ & $0.95 \pm 0.06$ & $0.08 \pm 0.01$ & $2.37 \pm 0.13$ & $10.52 \pm 0.99$ \\
\hline har $17 / 4 / 8$ & 11.0 & $30(43)$ & $24.8 \pm 3.3$ & $25.23 \pm 1.15$ & $1.26 \pm 0.10$ & $0.85 \pm 0.06$ & $0.06 \pm 0.01$ & $2.17 \pm 0.12$ & $11.61 \pm 0.82$ \\
\hline har $17 / 5 / 1$ & 1.4 & $22(28)$ & $44.3 \pm 8.0$ & $0.32 \pm 0.03$ & $1.28 \pm 0.11$ & $0.72 \pm 0.05$ & $0.17 \pm 0.02$ & $2.17 \pm 0.13$ & $0.15 \pm 0.02$ \\
\hline har $17 / 5 / 2$ & 1.6 & $20(36)$ & $42.8 \pm 6.8$ & $2.51 \pm 0.24$ & $1.36 \pm 0.11$ & $1.04 \pm 0.07$ & $0.17 \pm 0.02$ & $2.56 \pm 0.13$ & $0.98 \pm 0.10$ \\
\hline har $17 / 5 / 4$ & 3.7 & $23(46)$ & $19.2 \pm 2.9$ & $19.53 \pm 0.79$ & $1.23 \pm 0.11$ & $0.74 \pm 0.05$ & $0.13 \pm 0.01$ & $2.11 \pm 0.12$ & $9.27 \pm 0.64$ \\
\hline har $17 / 5 / 6$ & 5.7 & $20(46)$ & $27.9 \pm 4.8$ & $18.75 \pm 1.23$ & $1.21 \pm 0.11$ & $0.68 \pm 0.05$ & $0.11 \pm 0.01$ & $2.00 \pm 0.12$ & $9.38 \pm 0.82$ \\
\hline har $17 / 5 / 8$ & 8.7 & $24(33)$ & - & $>127$ & $1.44 \pm 0.11$ & $1.13 \pm 0.08$ & $0.08 \pm 0.01$ & $2.65 \pm 0.13$ & $>48$ \\
\hline har $17 / 6 / 2$ & 2.0 & $22(34)$ & $33.0 \pm 5.3$ & $0.84 \pm 0.06$ & $1.34 \pm 0.11$ & $0.95 \pm 0.06$ & $0.16 \pm 0.02$ & $2.44 \pm 0.13$ & $0.34 \pm 0.03$ \\
\hline har $17 / 6 / 4$ & 4.0 & $20(35)$ & $29.4 \pm 5.0$ & $3.72 \pm 0.26$ & $1.30 \pm 0.11$ & $0.83 \pm 0.06$ & $0.13 \pm 0.01$ & $2.26 \pm 0.12$ & $1.65 \pm 0.15$ \\
\hline har $17 / 6 / 6$ & 6.0 & $24(34)$ & $30.4 \pm 4.5$ & $20.08 \pm 1.07$ & $1.22 \pm 0.10$ & $0.82 \pm 0.05$ & $0.10 \pm 0.01$ & $2.14 \pm 0.12$ & $9.38 \pm 0.71$ \\
\hline har $17 / 6 / 9$ & 9.5 & $20(46)$ & $21.6 \pm 3.9$ & $22.10 \pm 1.15$ & $1.33 \pm 0.11$ & $0.96 \pm 0.06$ & $0.07 \pm 0.01$ & $2.35 \pm 0.12$ & $9.39 \pm 0.69$ \\
\hline
\end{tabular}




\section{Discussion}

Previous chronometric investigations of dunes in the northern Thar Desert have been limited and have focussed chiefly on transverse and parabolic dunes (Kar et al., 1998; Thomas et al., 1999). These studies often relied on sampling pre-existing exposures and used older and now mostly redundant multiple aliquot luminescence dating techniques (Duller, 2004). The ages from these studies provided evidence of mid to late- Holocene dune activity (Kar et al., 1998; Thomas et al., 1999; Singhvi and Kar, 2004). The oldest ages in our new suite of data are from full depth profiles of sites Thar $17 / 5$ and Thar $17 / 2$. Though these two ages of $>48 \mathrm{ka}$ (Thar 17/5/8) and $>58 \mathrm{ka}$ (Thar 17/2/10) are minimum age estimates, they are still considerably older than the records in previously published chronologies (Thomas et al., 1999; Singhvi and Kar, 2004), and provide the first reported occurrence of pre-Holocene dune activity in the northern Thar. This is important considering previous studies from southern, central and eastern Thar have presented dune records dating to $>50 \mathrm{ka}$ and attested to the antiquity of the desert (Chougaonkar et al., 1999; Dhir et al., 2010; Singhvi et al., 2010) while records from the northern Thar dunes were limited to the Holocene.

A significant component of our new dataset is evidence of early Holocene dune accumulation, and importantly this is recorded at all four sites, spanning $11.61 \pm 0.82$ ka to $8.62 \pm 0.64 \mathrm{ka}$ (Fig. $6 \mathrm{~B}$ ). Thick sediment accumulations are recorded during this period: $2 \mathrm{~m}$ and $3.5 \mathrm{~m}$ of sediment occurred at $\sim 9.4 \mathrm{ka}$ at sites Thar $17 / 5$ and Thar 17/6 respectively. At site Thar 17/2, a 4 m thick dune accumulation dates to slightly later $(\sim 8.8 \mathrm{ka})$, and at Thar $17 / 4$, the lowermost $7 \mathrm{~m}$ dune sand accumulated between $11.61 \pm 0.82 \mathrm{ka}$ and $8.79 \pm 0.67 \mathrm{ka}$. At this site this translates to an estimated accumulation rate of $\sim 2.5$ m.ka ${ }^{-1}$. Regionally, comparable early Holocene net accumulation rates have been reported from NE-SW trending linear dune studies in 
the monsoon dominated northeast Rub 'al-Khali Desert (Atkinson et al., 2011, 2012). The early Holocene has been identified as a period marked by strong monsoonal winds compared to the late Holocene, evidenced by the enhanced upwelling off the coast of Oman (Gupta et al., 2003; Fig. 7) and a large wind stress curl across the western Arabian Sea (Gill et al., 2017; Fig. 7). Within the Thar Desert, the parabolic dunefield $\sim 200 \mathrm{~km}$ south of the study area (Srivastava et al., 2019) and dunes associated with the Ghaggar-Hakra palaeochannel along the northern desert margin (Durcan et al., 2019) also recorded early Holocene accumulation. The data presented here demonstrate that the last major widespread dune accumulation in the Thar was not limited to the late glacial period $(\sim 17-\sim 11 \mathrm{ka})$, but that major aeolian dynamism persisted into the early Holocene until $\sim 8.6 \mathrm{ka}$.

In our study, only two dates identify mid to late-Holocene dune accumulation (4.07 \pm $0.44 \mathrm{ka}$ at Thar 17/2/2 and $3.01 \pm 0.24 \mathrm{ka}$ at Thar 17/4/1 (Table 2), both of which were sampled from within $1 \mathrm{~m}$ of the dune crest. The mid to late- Holocene dune activity, which resulted in thinner sediment accumulations compared to the early Holocene, suggests that dune activity in the region was less pervasive in terms of dune accumulation during the later part of the Holocene, with thicker units reflecting periods of more intensive dune activity (Telfer et al., 2010; ). Two sites (Thar 17/5 and 17/6) record seemingly more localised dune accumulation between $1.65 \pm 0.15-0.98 \pm 0.11$ ka, which could be spatially restricted in nature or the result of localised reworking within the dune system. Unlike the early Holocene, the age depth profiles are more variable between the four studied sites during the mid- and late-Holocene (Fig. 6B) suggesting that individual dune profiles do not capture temporally comprehensive accumulation phases even in a spatially intensive dunefield. Telfer et al. (2010) and Bailey and Thomas (2014), through their modelling work, have suggested that 
preservation potential is unlikely to be equal spatially and temporally within a dune system, due to the interaction of exogenous and endogenous (stochastic) influences on accumulation. Stone and Thomas (2008), in their study of linear dunes in southwest Kalahari, also showed that only some accumulation phases are consistently recorded between dunes and individual dune profiles do not offer a temporal record even for a small region. Here, the younger phases of dune accumulation are preserved in pockets in three studied dunes, while absent in Thar 17/4, where the uppermost sample $(0.5 \mathrm{~m}$ from the crest) yielded an age of $3.01 \pm 0.24 \mathrm{ka}$. The absence of any common accumulation phases dating to the late Holocene could be due to differential preservation between the dunes or phases being missed in sampling. However, sampling at shallow depth of $0.5 \mathrm{~m}$ at Thar $16 / 4$ should have minimised sampling bias towards younger phases. Likewise, at Thar 17/2 there is a jump from $0.58 \pm 0.05 \mathrm{ka}$ (Thar $17 / 2 / 1$ ) to $4.07 \pm 0.44 \mathrm{ka}$ (Thar $17 / 2 / 2$ ) over just $0.1 \mathrm{~m}$, where a bounding surface exists, suggests that missing an accumulation phase through sampling is not likely to be the major cause.

Although the INQUA Dunes Atlas chronologic database does not include any dated linear dune sites in the Thar, there are records from at least one dune site from Jamsar in the Bikaner region (Fig. 1B). Thomas et al. (1999) described the sampled feature as a linear dune site while later reviews designated it as a parabolic dune (Singhvi and Kar, 2004; Lancaster et al., 2016). Jamsar, which appears to be a linear dune site from Google Earth analysis, was a 3.9 m exposed dune section on the margins of an ephemeral lake studied by Thomas et al. (1999) and the authors reported 6 luminescence ages suggesting dune activity between $5.3 \pm 0.7 \mathrm{ka}$ and $4.7 \pm 0.9 \mathrm{ka}$, and within the last 2000 years (Fig. 7). These ages were calculated using the multiple aliquot additive dose (MAAD) protocol that was widely used in the early decades of 
392 luminescence dating applications to sediments. It must be noted that earlier protocols

393 did not explicitly check for changes in luminescence sensitivity, therefore potentially 394 adding an element of unreliability to them (Stokes et al., 2000; Duller, 2004). Duller 395 and Augustinus (2006) demonstrated the importance of checking the validity of 396 luminescence dating results obtained using older protocols by dating the same 397 samples from a stabilised linear dune in Tasmania and showed that MAAD protocol 398 methods overestimated $D_{e}$ values by up to $84 \%$ compared against SAR. Singhvi et 399 al. (2010) presented SAR and MAAD ages for four dune samples from the Thar where 400 MAAD ages overestimated the SAR ages by $15-53 \%$. It is therefore possible that 401 previously published ages from Jamsar dune feature (Thomas et al., 1999) are likely 402 maximum ages for sediment accumulation. 

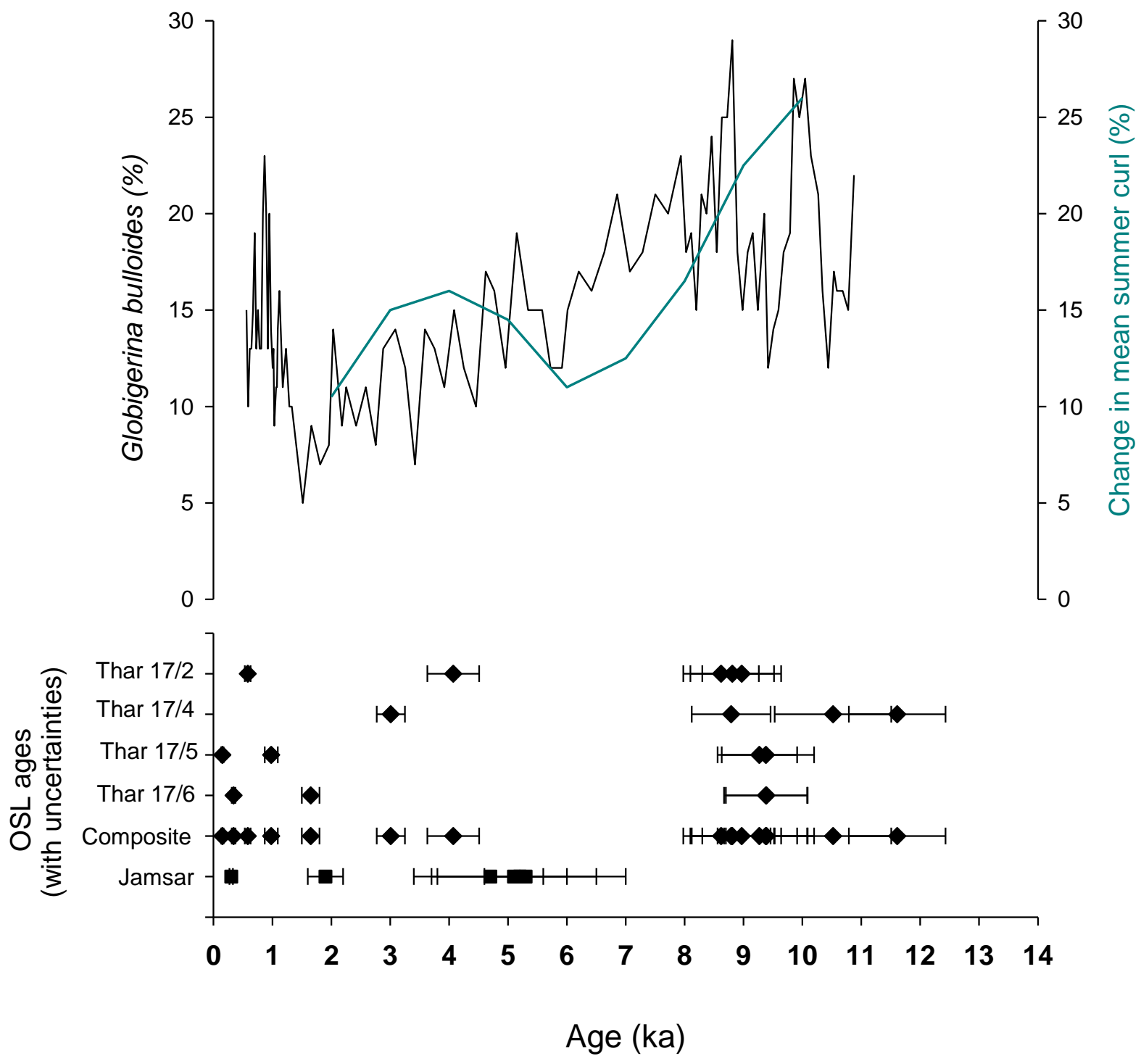

405

Fig. 7. Thar linear dune OSL ages plotted against reconstructions of G. bulloides percentage (Gupta et al., 2003) and percentage change in wind stress curl (blue) (Gill et al., 2017). The diamonds represent the ages determined in this study using post IR blue SAR protocol, while the squares are the MAAD OSL ages calculated by Thomas et al. (1999).

411 The ages from the last millennium have been calculated at the crestal parts of three 412 of the four studied dune sites (Fig. 6A). The site Thar $17 / 2$ recorded $0.8 \mathrm{~m}$ of dune 413 accumulation in last $\sim 500$ years, Thar $17 / 5$ recorded $1.4 \mathrm{~m}$ of accumulation in last 

$\sim 150$ years and Thar 17/6 recorded $2 \mathrm{~m}$ of accumulation in the last $\sim 350$ years. These thicker units reflect the preservation bias towards younger sediments (Bailey and Thomas, 2014) and the absence of any late Holocene feature at site Thar 17/4 further confirm that individual dune profiles only provide partial information about the past changes. The parabolic dunes in the vicinity of the study area have also witnessed dune accumulation in the last millennium but those are significantly widespread with higher accumulation rates (Srivastava et al., 2019). This difference in dune accumulation rates could be attributed to parabolic dunes being more sensitive to natural and anthropogenic disturbances (e.g., Hugenholtz and Wolfe, 2005; Girardi and Davis, 2010), and the changing landscape in the Thar (Srivastava et al., 2019 and references therein). Nevertheless, the modern ages not only suggest that the Thar linear dunes remained active in later parts of the Holocene but also questions whether these dunes can be grouped under an 'old system' as previously implied (e.g., Pandey et al., 1964; Kar, 1993; Singhvi and Kar, 2004). Similar active and partially-active linear dunes have also been reported from the Negev (Roskin et al., 2011a), the Kalahari (Telfer and Thomas, 2007), the Strzelecki (Lomax et al., 2003) and the Tirari Deserts (Fitzsimmons et al., 2007).

\section{Conclusions}

This study presents a suite of OSL ages from intensively sampled linear dunes in the Thar Desert, India. The dataset show variability in dune activity between sites in terms of timing and nature of dune accumulation. In general, the record is characterised by consistent and rapid dune accumulation in the early Holocene, and multiple, distinct phases during the mid and late Holocene. The early Holocene period is the most active dune accumulation period which correlates with other Thar dunes records (Srivastava et al., 2019) and wider regional geoproxy evidence. The OSL ages show that the linear 
dunes in the Thar have remained active, accumulating sediment during the Holocene.

440 The accumulation of up to $2 \mathrm{~m}$ of dune sediment in recent times rules out the earlier notion of classifying linear dunes as belonging to an 'old' Thar Desert system. The suite of ages also presents the first reported records of pre-Holocene dune activity in the northern Thar, albeit as minimum ages, and affirms findings from other desert dunefields that linear dunes preserve a relatively longer chronology. As dune records are increasingly being incorporated to wider palaeoenvironmental studies, our study emphasises on the importance of intensive dunefield sampling, rather than focusing on single dune profiles which do not capture temporally comprehensive accumulation phases, as done in the majority of previous studies in the Thar.

\section{Acknowledgments}

The doctoral studies of the first author are funded by the Clarendon Scholarship, University of Oxford. The authors thank the John Fell Fund, University of Oxford (Grant Number 132/062) for providing funding for fieldwork and lab analyses. The first author also thanks the International Society for Aeolian Research for supporting attendance at the 10th International Conference on Aeolian Research in Bordeaux (2018), where this work was initially presented. The authors thank the anonymous reviewers for their comments and suggestions.

\section{References}

Atkinson, O. A., Thomas, D. S. G., Goudie, A. S., Bailey, R. M., 2011. Late Quaternary chronology of major dune ridge development in the northeast Rub'al-Khali, United Arab Emirates. Quaternary Research 76, 93-105. development of multiple dune generations in the northeast Rub'al-Khali, United Arab Emirates. The Holocene 22, 179-189. 
Atkinson, O. A., Thomas, D. S. G., Parker, A. G., Goudie, A. S., 2013. Late Quaternary humidity and aridity dynamics in the northeast Rub'al-Khali, United Arab Emirates: implications for early human dispersal and occupation of eastern Arabia. Quaternary International 300, 292-301.

Bailey, R. M., Thomas, D. S. G., 2014. A quantitative approach to understanding dated dune stratigraphies. Earth Surface Processes and Landforms 39, 614-631.

Banerjee, D., Murray, A. S., Bøtter-Jensen, L., Lang, A., 2001. Equivalent dose estimation using a single aliquot of polymineral fine grains. Radiation Measurements 33, 73-94.

Bateman, M. D., Boulter, C. H., Carr, A. S., Frederick, C. D., Peter, D., Wilder, M., 2007. Detecting post-depositional sediment disturbance in sandy deposits using optical luminescence. Quaternary Geochronology 2, 57-64.

Bateman, M. D., Frederick, C. D., Jaiswal, M. K., Singhvi, A. K., 2003. Investigations into the potential effects of pedoturbation on luminescence dating. Quaternary Science Reviews 22, 1169-1176.

Bell, W. T., 1979. Attenuation factors for the absorbed radiation dose in quartz inclusions for thermoluminescence dating. Ancient TL 8, 12.

Blott, S. J., Pye, K., 2001. GRADISTAT: a grain size distribution and statistics package for the analysis of unconsolidated sediments. Earth surface processes and

Bullard, J. E., Thomas, D. linear sand dune

D. S. G., Livingstone, Desert. Geomorphology 11, 189-203.

Chougaonkar, M. P., Raghav, M. S., Rajaguru, S. N., Kar, A., Singhvi, A. K., Nambi, desert and their implications. Man Environ 24, 21-26.

Cunningham, A. C., DeVries, D. J., Schaart, D. R., 2012. Experimental and computational simulation of beta-dose heterogeneity in sediment. Radiation Measurements 47, 1060-1067.

Cunningham, A. C., Wallinga, J., Minderhoud, P. S., 2011. Expectations of scatter in equivalent-dose distributions when using multi-grain aliquots for $\mathrm{OSL}$ dating. Geochronometria 38, 424.

Dhir, R. P., Singhvi, A. K., Andrews, J. E., Kar, A., Sareen, B. K., Tandon, S. K., Kailath, A. Thomas, J. V., 2010. Multiple episodes of aggradation and calcrete formation in Late Quaternary aeolian sands, Central Thar Desert, Rajasthan, India. Journal of Asian Earth Sciences 37, 10-16. 
Duller, G. A. T., 2004. Luminescence dating of Quaternary sediments: recent advances. Journal of Quaternary Science 19, 183-192.

503

504

505

506

507

508

509

510

511

512

513

514

515

516

517

518

519

520

521

522

Duller, G. A. T., Augustinus, P. C., 2006. Reassessment of the record of linear dune activity in Tasmania using optical dating. Quaternary Science Reviews 25, 2608-2618.

Durcan, J. A., Duller, G. A. T., 2011. The fast ratio: a rapid measure for testing the dominance of the fast component in the initial OSL signal from quartz. Radiation Measurements 46, 1065-1072.

Durcan, J. A., King, G. E., Duller, G. A. T., 2015. DRAC: Dose Rate and Age Calculator for trapped charge dating. Quaternary Geochronology 28, 54-61.

Durcan, J. A., Thomas, D. S. G., Gupta, S., Pawar, V., Singh, R. N., Petrie, C. A., 2017. Holocene landscape dynamics in the Ghaggar-Hakra palaeochannel region at the northern edge of the Thar Desert, northwest India. Quaternary International.

Fitzsimmons, K. E., Rhodes, E. J., Magee, J. W., Barrows, T. T., 2007. The timing of linear dune activity in the Strzelecki and Tirari Deserts, Australia. Quaternary Science Reviews 26, 2598-2616.

Folk, R. L., Ward, W. C., 1957. Brazos River bar, Texas- a study in the significance of grain size parameters. Journal of Sedimentary Research 27, 3-26.

Galbraith, R. F., Roberts, R. G., Laslett, G. M., Yoshida, H., Olley, J. M., 1999. Optical dating of single and multiple grains of quartz from Jinmium rock shelter, northern Australia: Part I, experimental design and statistical models. Archaeometry 41, 339364.

Gill, E. C., Rajagopalan, B., Molnar, P. H., Kushnir, Y., Marchitto, T. M., 2017. Reconstruction of Indian summer monsoon winds and precipitation over the past 10,000 years using equatorial pacific SST proxy records. Paleoceanography 32, 195216.

Girardi, J. D., Davis, D. M., 2010. Parabolic dune reactivation and migration at Napeague, NY, USA: Insights from aerial and GPR imagery. Geomorphology 114, 530-541.

Glennie, K. W., Singhvi, A. K., 2002. Event stratigraphy, paleoenvironment and chronology of SE Arabian deserts. Quaternary Science Reviews 21, 853-869.

Guerin, G., Jain, M., Thomsen, K. J., Murray, A. S., Mercier, N., 2015. Modelling dose rate to single grains of quartz in well-sorted sand samples: The dispersion arising from the presence of potassium feldspars and implications for single grain OSL dating. Quaternary Geochronology 27, 52-65.

Guérin, G., Mercier, N., Adamiec, G., 2011. Dose-rate conversion factors: update. Ancient TL 29, 5-8. 
Guérin, G., Mercier, N., Nathan, R., Adamiec, G., Lefrais, Y., 2012. On the use of the infinite matrix assumption and associated concepts: a critical review. Radiation Measurements 47, 778-785.

Gupta, A. K., Anderson, D. M., Overpeck, J. T., 2003. Abrupt changes in the Asian southwest monsoon during the Holocene and their links to the North Atlantic Ocean. Nature 421, 354-357.

Heer, A. J., Adamiec, G., Moska, P., 2012. How many grains are there on a single aliquot. Ancient TL 30, 9-16.

Heiri, O., Lotter, A. F., Lemcke, G., 2001. Loss on ignition as a method for estimating organic and carbonate content in sediments: reproducibility and comparability of results. Journal of paleolimnology 25, 101-110.

Hugenholtz, C. H., Wolfe, S. A., 2005. Recent stabilization of active sand dunes on the Canadian prairies and relation to recent climate variations. Geomorphology 68, 131-147.

Jankowski, N. R., Jacobs, Z., 2018. Beta dose variability and its spatial contextualisation in samples used for optical dating: An empirical approach to examining beta microdosimetry. Quaternary Geochronology 44, 23-37.

Kar, A., 1987. Origin and transformation of longitudinal sand dunes in the Indian desert. Zeitschrift fur Geomorphologie 31, 311-337.

Kar, A., 1993. Aeolian processes and bedforms in the Thar Desert. Journal of Arid Environments 25, 83-96.

Kar, A., 2014. The Thar or the Great Indian Sand Desert. In Landscapes and Landforms of India 79-90. Springer, Dordrecht.

Kar, A., Felix, C., Rajaguru, S. N., Singhvi, A. K., 1998. Late Holocene growth and mobility of a transverse dune in the Thar Desert. Journal of Arid Environments 38, 175185.

Kar, A., Singhvi, A. K., Rajaguru, S. N., Juyal, N., Thomas, J. V., Banerjee, D., Dhir, R. P., 2001. Reconstruction of the late Quaternary environment of the lower Luni plains, Thar Desert, India. Journal of Quaternary Science: Published for the Quaternary Research Association 16, 61-68.

Kreutzer, S., Dietze, M., Burow, C., Fuchs, M. C., Schmidt, C., Fischer, M., Friedrich, J., 2017. Luminescence: Comprehensive luminescence dating data analysis. $R$ package version 0.7.3.

Kristensen, J. A., Thomsen, K. J., Murray, A. S., Buylaert, J. P., Jain, M., BreuningMadsen, H., 2015. Quantification of termite bioturbation in a savannah ecosystem: application of OSL dating. Quaternary Geochronology 30, 334-341. 
Kumar, M., Goossens, E., Goossens, R., 1993. Assessment of sand dune change detection in Rajasthan Thar Desert, India. International Journal of Remote Sensing 14, 1689-1703.

Lancaster, N., 1982. Linear dunes. Progress in Physical Geography 6, 475-504.

Lancaster, N., Wolfe, S., Thomas, D.S.G. , Bristow, C., Bubenzer, O., Burrough, S. L., Duller, G., Halfen, A., Hesse, P.P., Roskin, J. and Singhvi, A. K., 2016. The INQUA dunes atlas chronologic database. Quaternary international 410, 3-10.

Leighton, C. L., Bailey, R. M., Thomas, D. S. G., 2013. The utility of desert sand dunes as Quaternary chronostratigraphic archives: evidence from the northeast Rub'al Khali. Quaternary Science Reviews 78, 303-318.

Livingstone, I., Thomas, D. S. G., 1993. Modes of linear dune activity and their palaeoenvironmental significance: an evaluation with reference to southern African examples. Geological Society, London, Special Publications 72, 91-101.

Lomax, J., Hilgers, A., Wopfner, H., Grün, R., Twidale, C. R., Radtke, U., 2003. The onset of dune formation in the Strzelecki Desert, South Australia. Quaternary Science Reviews 22, 1067-1076.

Mayya, Y. S., Morthekai, P., Murari, M. K., Singhvi, A. K., 2006. Towards quantifying beta microdosimetric effects in single-grain quartz dose distribution. Radiation Measurements 41, 1032-1039.

Moharana, P. C., Gaur, M. C., Choudhary, C., Chauhan, J. S., Rajpurohit, R. S., 2013. A system of geomorphological mapping for western Rajasthan with relevance for agricultural land use. Annals of Arid Zone 52, 163-180.

Munyikwa, K., 2005. The role of dune morphogenetic history in the interpretation of linear dune luminescence chronologies: a review of linear dune dynamics. Progress in Physical Geography 29, 317-336.

Murray, A. S., Funder, S., 2003. Optically stimulated luminescence dating of a Danish Eemian coastal marine deposit: a test of accuracy. Quaternary Science Reviews 22, 1177-1183.

Murray, A. S., Wintle, A. G., 2003. The single aliquot regenerative dose protocol: potential for improvements in reliability. Radiation measurements 37, 377-381.

Murray, A.S., Wintle, A. G., Wallinga, J., 2002. Dose estimation using quartz OSL in the non-linear region of the growth curve. Radiation Protection Dosimetry 101, 371374.

Nathan, R. P., Thomas, P. J., Jain, M., Murray, A. S., Rhodes, E. J., 2003. Environmental dose rate heterogeneity of beta radiation and its implications for luminescence dating: Monte Carlo modelling and experimental validation. Radiation Measurements 37, 305-313. 
O'Connor, P. W., Thomas, D. S. G., 1999. The timing and environmental significance of late Quaternary linear dune development in western Zambia. Quaternary Research 52, 44-55.

Olley, J. M., Pietsch, T., Roberts, R. G., 2004. Optical dating of Holocene sediments from a variety of geomorphic settings using single grains of quartz. Geomorphology 60, 337-358.

Pandey, S., Singh, S., Ghose, B., 1964. Orientation, distribution and origin of sand dunes in the central Luni basin. In Proceedings, Symposium on Problems of Indian Arid Zone, 84-91.

Parton, A., Farrant, A. R., Leng, M. J., Telfer, M. W., Groucutt, H. S., Petraglia, M. D., Parker, A. G., 2015. Alluvial fan records from southeast Arabia reveal multiple windows for human dispersal. Geology 43, 295-298.

Prescott, J. R., Hutton, J. T., 1994. Cosmic ray contributions to dose rates for luminescence and ESR dating: large depths and long-term time variations. Radiation measurements $23,497-500$.

Roskin, J., Porat, N., Tsoar, H., Blumberg, D. G., Zander, A. M., 2011a. Age, origin and climatic controls on vegetated linear dunes in the northwestern Negev Desert Israel. Quaternary Science Reviews 30, 1649-1674.

Roskin, J., Tsoar, H., Porat, N., Blumberg, D. G., 2011b. Palaeoclimate interpretations of Late Pleistocene vegetated linear dune mobilization episodes: evidence from the northwestern Negev dunefield, Israel. Quaternary Science Reviews 30, 3364-3380.

Saxena, S. K., Singh, S., 1976. Some observations on the sand dunes and vegetation of Bikaner district in Western Rajasthan, India. Annals of Arid Zone.

Singhvi, A. K., Kar, A., 2004. The aeolian sedimentation record of the Thar Desert. Journal of Earth System Science 113, 371-401.

Singhvi, A. K., Porat, N., 2008. Impact of luminescence dating on geomorphological and palaeoclimate research in drylands. Boreas 37, 536-558.

Singhvi, A. K., Williams, M. A. J., Rajaguru, S. N., Misra, V. N., Chawla, S., Stokes, Chauhan, N., Francis, T., Ganjoo, R., Humphreys, G. S., 2010. A 200 ka record of climatic change and dune activity in the Thar Desert, India. Quaternary Science Reviews 29, 3095-3105.

Srivastava, A., Thomas, D. S. G., Durcan, J. A., 2019. Holocene dune activity in the Thar Desert, India. Earth Surface Processes and Landforms 44, 1407-1418.

Stokes, S., Thomas, D. S. G., Shaw, P. A., 1997. New chronological evidence for the nature and timing of linear dune development in the southwest Kalahari Desert. Geomorphology 20, 81-93. 
Stone, A. E. C., Thomas, D. S. G., 2008. Linear dune accumulation chronologies from the southwest Kalahari, Namibia: challenges of reconstructing late Quaternary palaeoenvironments from aeolian landforms. Quaternary Science Reviews 27, 16671681.

Telfer, M. W., Bailey, R. M., Burrough, S. L., Stone, A. E. S., Thomas, D. S. G., Wiggs, G. F. S., 2010. Understanding linear dune chronologies: insights from a simple accumulation model. Geomorphology 120, 195-208.

Telfer, M. W., Hesse, P. P., 2013. Palaeoenvironmental reconstructions from linear dunefields: recent progress, current challenges and future directions. Quaternary Science Reviews 78, 1-21.

Telfer, M. W., Thomas, D. S. G., 2007. Late Quaternary linear dune accumulation and chronostratigraphy of the southwestern Kalahari: implications for aeolian palaeoclimatic reconstructions and predictions of future dynamics. Quaternary Science Reviews 26, 2617-2630.

Thomas, D. S. G., 1992. Desert dune activity: concepts and significance. Journal of Arid Environments 22, 31-38.

Thomas, D. S. G., 2013. Reconstructing paleoenvironments and palaeoclimates in drylands: what can landform analysis contribute? Earth Surface Processes and Landforms 38, 3-16.

Thomas, D. S. G., Shaw, P. A., 1991. The Kalahari Environment. Cambridge University Press.

Thomas, J. V., Kar, A., Kailath, A. J., Juyal, N., Rajaguru, S. N., Singhvi, A. K., 1999. Late Pleistocene-Holocene-history of aeolian accumulation in the Thar Desert, India. Zeitschrift fur Geomorphologie Supplementband 181-194.

Thomsen, K. J., Murray, A. S., Bøtter-Jensen, L., 2005. Sources of variability in OSL dose measurements using single grains of quartz. Radiation Measurements 39, 4761.

Thomsen, K. J., Murray, A. S., Jain, M., 2012. The dose dependency of the overdispersion of quartz OSL single grain dose distributions. Radiation Measurements 47, 732-739.

Tsoar, H., 1989. Linear dunes-forms and formation. Progress in Physical Geography 13, 507-528.

Tsoar, H., Blumberg, D. G., Wenkart, R., 2008. Formation and geomorphology of the North-Western Negev sand dunes. In Arid dune ecosystems, 25-48. Springer, Berlin, Heidelberg.

Tsoar, H., Møller, J. T., 1986. The role of vegetation in the formation of linear sand dunes. Aeolian geomorphology 75-95. 
683 Verstappen, H. T., 1968. On the origin of longitudinal seif dunes. Zeitschrift für 684 Geomorphologie NF 12, 200-220.

685 Wasson, R. J., Rajaguru, S. N., Misra, V. N., Agrawal, D. P., Dhir, R. P., Singhvi, A. 686 K., Rao, K. K., 1983. Geomorphology, late Quaternary stratigraphy and 687 palaeoclimatology of the Thar dunefield.

688 Wintle, A. G., Murray, A. S., 2006. A review of quartz optically stimulated 689 luminescence characteristics and their relevance in single-aliquot regeneration dating 690 protocols. Radiation measurements 41, 369-391.

691

692 